\title{
Impact of Climate Change on Apple Phenology and Adaptability of Anna Variety (Low Chilling Cultivar) in Lower Hills of Uttarakhand
}

\author{
Pankaj Nautiyal*, Ritika Bhaskar, Gaurav Papnai, Neeraj Joshi and Varun Supyal \\ Krishi Vigyan Kendra, ICAR-VPKAS, Chinyalisaur-249146, Distt \\ Uttarkashi, Uttarakhand, India \\ *Corresponding author
}

\section{Keywords}

Climate Change, Apple, Snowfall,

Hailstorm, Low

Chilling Variety,

Phenology, Bud

burst

Article Info

Accepted:

07 August 2020

Available Online:

10 September 2020

\begin{abstract}
A B S T R A C T
Apple being a temperate fruit is been widely grown under a large area in the Himalayan regions of India because of the favorable climatic conditions. Mountains are however amongst the most fragile experiencing extreme weather conditions, like rising temperature, uneven precipitation, spring hailstorms, and cold waves which severely affect the production of temperate crops. The traditional apple cultivation in Uttarakhand hills is under stress due to climate change. The instances of these adverse conditions impact could be observed on plant phenology, bud bursting, blossoming, fruit retention, fruit yield and quality. The rising temperature widely affects the chilling requirement for apple fruit, which is the pre-requisite for blossoming of apple fruit. Insufficient chilling greatly influence fruit set whereas, hailstorm during spring season causes frost injury and deteriorate the fruit quality. Evidences of poor climatic condition leads to the shifting of apple cultivation towards crop like kiwi and pomegranate. Development of low chill cultivars with greater adaptation is the viable approach that can be adopted to fetch good production of apple fruit and to maintain the commercial importance of apple fruit in hilly regions. Under the stressful condition, Anna variety of apple performs well and can with stand under low chilling requirements in lower hills of Uttarakhand.
\end{abstract}

\section{Introduction}

Apple (Malus pumila) belongs to family Rosaceae. It is a temperate fruit, grown between 1500 - 2600 meter above mean sea level (Wani and Songara, 2017). Being deciduous in nature, apple favors cool temperature for better growth, to break dormancy and bud development. The major apple growing states in India are Jammu and Kashmir, Himachal Pradesh and Uttarakhand, which covers 95.4 per cent of total area under apple and 98.7 per cent of the total apple production. In India, it is cultivated on 3.01 lakh ha with production of 23.27 lakh MT and productivity of $7.73 \mathrm{t} / \mathrm{ha}$ (NHB 2018). In India, Uttarakhand state is well known for the horticultural crops, including apple and citrus occupying top production. Among other crops, maltas, mandarin, lime, gal gal are mostly cultivated citrus fruits. About 25201 ha area in Uttarakhand is under apple cultivation (Chimwal et al., 2019). 
Several factors are attributed to the declining trend in apple productivity, like insufficient nutrient and moisture availability, deteriorating soil water management, prevalence of diseases and pests and majorly the climatic shifts (Nautiyal and Dimri, 2009; Nautiyal et al., 2017). Climate change poses serious impact on agriculture, horticulture, environment and health all over the world (Verma et al., 2019). The evidences of significant climate changes in India showing increasing trends in annual temperature with an average of $0.56^{\circ} \mathrm{C}$ rise over the last 100 years (Rao et al., 2009; IMD, 2010). The global mean temperature of the earth's surface has increased by about $0.74^{\circ} \mathrm{C}$ (IPCC (2007a). Due to global warming and abnormal rainfall patterns, there is continues failure of crop in autumn season (Sharma et al., 2020). Increase in temperature could well affect the sustained fresh water resources through accelerated melting of glaciers and snow in the high mountain areas (Hussain et al., 2005). Himalayan regions show very wide range of climate change and are very much susceptible to these changes. Uneven spatial and temporal variation of rainfall, frequent drought conditions and low crop production has been noticed at various districts in Uttarakhand (Isaac and Isaac, 2017). Climatic changes like increasing temperature and uneven/less precipitation are the major extremes affecting apple production. From the past 30 years, the average mean temperature in hilly regions has risen between $0.44^{\circ} \mathrm{C}$ to $0.59{ }^{\circ} \mathrm{C}$ severely affecting high-chill fruits like apple, walnut, apricot, almond, cherry etc) and warming scenario exceeding $1.5^{\circ} \mathrm{C}$ would expected to increase the risk of prolonged dormancy for both stone and pome-fruits (Ahmed et al., 2019). Rise in temperature and rapid snow cover melting adversely affected apple cultivation in lower Himalayas, since many years (Sharma et al., 2013). Increasing minimum temperatures under climate change may induce insufficient chilling accumulation resulting in uneven or delayed bud break. Exposing horticultural crops to increased heat stress causes physiological disorders. Colour development in apples occurs through the production of anthocyanin reduces due to high temperature (Verma et al.2019). Unusual hailstorms and windstorms during summer season, fruits like cherry, apple, plum, peach and apricot were severly damaged (Chaudhary et al., 2015).

Increased temperature during winters considerably resulted precipitation in form of rain in spite of snow and easy snow melting causing heavy soil loss along with nutrients. Rise in temperature results in flourishing vegetative growth but retarded reproductive growth. Changing climate probably increased atmospheric winter temperature results in incompetent chilling and forcing requirement essential for the end of apple dormancy (Legave et al., 2013; Vitasse et al., 2018). Increase in temperature may affect overwinter chill requirements of temperate tree fruits and require replacement by new cultivars or species (Stockle et al., 2010).

There is sharp decrease on overall precipitation especially during winters (Jethi et al., 2016). In recent years, problem of low snowfall intensity became a huge problem in hilly regions, due to continuous snowfall depletion year by year, resulting less snow on glaciers and reduced stream flow. The snow melting in hilly regions reduces chilling requirement which is essential for the bud burst and brings out the plant as dormant. Chilling requirement above 1000 chilling hours is essential for apple (Haokip et al., 2020). Change in snowfall pattern alters the timing of bearing, blossoming of the apple, affecting fruit yield and quality under Western Himalayan condition of India (Vedwan and Rhoades, 2001). Snowfall considered as an important constant for various climatologically and hydrological 
applications. It helps in maintaining the earth radiation budget balance. Snow cover greatly influenced the earth radiation balance when the total incoming radiations are the greatest in spring season (April- May). In Himalayan regions, snow melting or glacier melting is considered to be the richest source of freshwater required for drinking, agricultural \& industrial services, and for domestic purposes.

In addition to this, changes in temperature and precipitation could also expand vector-borne diseases into previously uninfected high altitude locations (Patz et al., 2005).The impact of climate change on apple productivity causes infestation of some diseases and pests resulting in more losses in yield (Parmesan, 2007).

In most of the districts of Himachal Pradesh, overall decrease of about 2-3\% of apple yield has been reported under the influence of changing climate (Bhagat et al., 2009). Reduction in chilling temperature or climate change drastically affected fruit production in the recent years especially apple production and farmers shifting the area of apple into production of coarse grains, seasonal vegetables and other horticulture species rather than apple cultivation (Singh et al., 2016).

\section{Impact of climate change on apple production in hilly regions}

In response to climate change under hilly regions, the apple production is highly affected. The impacts of climate change on the growth and development of apple fruit are discussed below:

\section{Impact on phenology}

The physiological activity of plant influenced by variation in climate is termed as phenology
(Cleland et al., 2007). The phonological stages including bud swell, bud break, full bloom, flower induction and differentiation, fruit development, maturation yield and quality are affected by climate changes, specifically temperature. In temperate fruit crops, flower induction is highly responsive to temperature and requires low temperature (less than $7^{\circ} \mathrm{C}$ for the fulfillment of adequate chilling hours. Flower induction deeply influenced by low temperature, however, strong interaction between genotype, photoperiod and temperature interactively control flowering (Rai et al., 2015). Though, climate warming during winters leads to rapid fulfillment of heat requirement causing variation in both flowering time and flowering duration.

\section{Impact on pattern of blooming}

Rise in temperature and lack of precipitation during winters alters the pattern of blossoming and bearing of apple under Himalayan regimes hence affecting yield as well as quality of the fruit. Under apple cultivation, most of the low altitude zones do not fulfill winter chilling due to rise in temperature, thus, flower bud produces fruit clusters resulting in delayed bloom period (Basannagari and Kala, 2013). Increased temperature leads to earlier flowering which conquers with the time of spring frost causing risk of frost damage to apple flowers (Blanke and Kunz, 2011). This could increase the risk for frost injury, ultimately results in poor fruit set and low yield. Whereas, decreased chilling hours due to less snowfall and rainfall during winter months causes abnormal pattern of bud-break and subsequently reduce flowering percentage. Lack of chilling in mild winter conditions result in abnormal pattern of budbreak (Ameglio et al., 2000). The apple tree requires 1200-1500 hours of chilling below $7^{\circ} \mathrm{C}$ depending on the type of cultivar. Chilling hour less than 1000 leads to low 
yield with poor quality (Rai et al., 2015).Extreme low temperature (Below $0^{\circ} \mathrm{C}$ and frost occurrence in apple and other temperate crops during bloom stage damages the flower buds (Haokip et al., 2020). Moreover, hailstorms during flower blooming cause major loss resulting less fruiting and hence low productivity. In addition to this, an uneven hailstorm also damages the crops (Meena et al., 2015).

\section{Impact on dormancy and chilling requirement}

Dormancy is a mechanism by which plants protects sensitive tissue from unfavorable climatic condition (Compay et al., 2011b). The delay in blooming dates of many trees indicates that dormancy breaking processes are indeed changing, most likely in response to climate change (Legave et al., 2013). Successful commercial cultivation of various fruit trees in temperate regions can be achieved by providing adequate winter chilling requirement. Chilling requirement is defined as the number of effective chilling hours needed to restore bud growth potential in spring (Richardson et al., 1974). The winter chilling requirements for most of the varieties is 500 to $1000 \mathrm{hrs}$ below $7^{\circ} \mathrm{C}$. In response to continuous increasing atmospheric temperature during winters, limited chilling hours for temperate crops is a problem that causes poor bud burst and leads to anomalous fruit growth (Petri and Leite, 2004).

This results in varying crop sizes and irregular maturity of fruits, which substantially reduce yield and also the fruit quality. Melting of ice cap in the Himalayan regions will reduce chilling effect required for the flowering of many of the horticultural crops like apple, cheery etc (Datta, 2013). Insufficient chilling requirements due to warming results in bud break failure and enhanced dormancy. To overcome the problem of insufficient chilling, chemical defoliation of apple can be done by copper sulphate or urea which enhances sprouting of buds (Rai et al., 2015).

\section{Impact on fruit quality}

Adverse climate condition during spring season when temperature go fairly low at the time of flowering and fruit setting usually causes frost injury and damage to the apple fruit. Occurrences of hailstorm directly damage the plants and force them to remain in vegetative and delay reproductive phase which ultimately affects fruit set. It also causes damage to the flowers and to the developing fruits at various stages of growth and development and ultimately results in low retention of fruit and poor yields. Frost injury due to intensively low temperature during spring season damages flower and fruit set which results in poor yield (Awasthi et al., 2001).

Also, rise in global temperature may also affect the post-harvest quality of the fruit. Temperature alteration have significant impact on the postharvest quality and quality parameters such as synthesis of sugars, organic acids, antioxidant compounds, peel colour and firmness (Moretti et al., 2010).

\section{Impact on pollination}

The incidence of spring frost and low temperature at the peak time of fruit setting adversely affects production of fruits. Along with low temperature and untimely rainfall occurrence inhibits pollen transfer due to washing-off of pollen. It has been observed that the flowers are killed below $-2.2^{\circ} \mathrm{C}$ and bee activity is completely retarded below $4.4^{\circ} \mathrm{C}$ (Awasthi et al., 2001). Also, flower induction in temperate fruits is deeply influenced by temperature especially by low temperature, however, strong interaction between genotype, photoperiod and 
temperature interactively control flowering (Haokip et al., 2020).Therefore, varying climatic conditions at the time of flowering and fruit setting will affects pollination and eventually the fruit production. The optimum temperature for pollination and fertilization in temperate fruits like apple, pear, plum, cherry etc is between $20-25^{\circ} \mathrm{C}$. Low temperatures and rainy or foggy conditions observed to have a negative effect during pollination in cherry in USA (Zavalloni et al., 2008).

\section{Approach to manage the effect of climate change in apple}

In order to cope up with the increasing unavoidable and undesirable risks related to increased atmospheric temperature, uneven precipitation, frost risk, adaptation measure must be needed. According to the IPCC Third Assessment Report, adaptation has the potential to reduce adverse impacts of climate change and to enhance beneficial impacts (IPCC 2007b). For the better horticultural production, the evidences of less snow fall intensity should not be underestimated. Reevaluation of the fruit varieties as per the indicated climate changes is imperative for planning a new orchard. To ensure better production, introduction and adaptation of low chilling (less than $800 \mathrm{hrs}$ ) fruit varieties like apple, peach, pear and plum in certain areas of lower hills and North Indian plains could be grown commercially. Some apple low chill cultivars are successfully adapted under stressed conditions especially in temperate regions are Anna, Mayan, Tamma Vered, Tropical Beauty, Parlin's Beauty, Schlomit, Michel, Neomi (Rai et al., 2015).

\section{Predicted varietal solution for apple cultivation in lower hills of Uttrakhand}

The cultivar is "Anna" was developed by A. Stein in Israel in 1965. It has very low chilling requirement i.e. $300 \mathrm{hrs}$. and could be grown in areas with limited chilling (Carter, 2007). The Anna variety i.e. Low chilling cultivars require warmer climate and is grown in low, mid hills and even in land with gentle slope for proper flowering and fruiting. The limiting factors in low chilling cultivation are the minimum winter temperature, spring frost, hailstorm, high humidity and desiccating winds during summer. Also, for intensive apple growing, Anna cultivar grafted on M9 and MM 111 rootstock performs well and recorded highest fruit set percentage $(22.6 \%)$ in comparison to Red Delicious, Granny Smith and Gala Smith apple cultivar (Ali and Ibrahim., 2019).Among all the low chilling cultivars of apple, Anna varieties showed the best result in terms of fruit size, colour and firmness.

Since, Uttarakhand state covers both Himalayan and plains regions, the low chilling varieties can be successfully planted in any region as the cultivar could resist under low chilling requirement and could be helpful in improving the socio-economic condition of Uttarakhand.

In conclusion the knowing how the climate influences production in terms of quantity as well as quality of the fruit. The prevailing climatic conditions in Himalayan regions like temperature fluctuates, inadequate chilling requirements, enhanced instances of hailstorms and rainfall leads to poor pollination,sub standard flower retention and fruit setting and results in poor productivity of apple fruit. As a result, the negative impact of these changes on quality and quantity and ultimately on commercial production of apple fruit have to be extricated by adaptation measures. It is necessary to acquire strategy to cope up with these incompetent weather conditions and to bring out better way to adapt under the same conditions. Considering, bloom delayed in spring due to insufficient chilling a major problem, so cultivating low 
chill cultivars of apple is the best adaptive measure to maintain the commercial importance of apple fruit in Uttarakhand hills.

\section{References}

Ahmed N., Lone F.A., Hussain K. Kanth, Mahdi S.S. 2019.Impact of climate on temperate Fruit Production in Kashmir Valley, North Western Himalayan Region of India - Challenges, Opportunities and Way Forward. Springer International Publishing AG (e Book) pp. 261-272.

Ameglio T, Alves G, Bonhomme M, Cochard $\mathrm{H}$, ewres $\mathrm{F}$, et al., 2000. Winter functioning of walnut: involvement in branching processes. In: L'Arbre, Biologieet development, Montreal (CAN), Isabelle Quentin: pp. 230-238.

Awasthi R. P., Verma H. S., Sharma R. D., Bhardwaj S. P. and Bhardwaj S. V. 2001. Causes of low productivity in apple orchards and suggested remedial measures. In: Jindal KK, Gautam DR, editors. Productivity of Temperate Fruits. Solan: Dr. Y.S Parmar University of Horticulture and Forestry: pp 1-8.

Basannagari B. and Kala C.P.2013. Climate Change and apple farming in Indian Himalayas: A study of Local Perception and Responses

Bhagat R.M., Rana R.S. and Kalia V. 2009. Global Climate Change and Indian Agriculture ICAR, New Delhi, Aggarwal PK (ed), pp. 48-53.

Blanke M.M. and Kunz A. 2011. Effects of climate change on pome fruit phenology and precipitation. ActaHort 922: 381-386.

Campoy J.A., Ruiz D. and Egea J. 2011b. Dormancy in temperate fruit trees in a global warming context: a review. SciHortic 130: 357-372.

Carter K., 2007. Low Chill Apples.
University of California Cooperative Extension Central Coast \& South Region.Pp 2-3

Chhimwal M., Pandey R. K. and Srivastava R. K. 2019. Status of agriculture and horticulture farming in the hill state of India- Uttarakhand. Journal of Pharmacognosy and Phytochemistry. 8(4): 1626-1631

Choudhary, M. L., Patel, V. B., Siddiqui, M. W., \& Mahdi, S. S. (2015). Climate dynamics in horticultural science volume-I: Principles and applications. Cambridge: Apple academic press.

Cleland E. E., Chuine I., Menzel A., Mooney H. A. and Schwartz M. D. 2007. Shifting plant phenology in response to global change. Ecology and Environment. 22: 357-365

Datta S. 2013. Impact of Climate Change in Indian Horticulture - A Review. 2: 661-671.

Haokip S. W., Shankar K. and Lalrinngheta J. 2020. Climate change and its impact on fruit crops. Journal of Pharmacognosy and Phytochemistry. 9(1): 435-438.

Hussain S. S., Mudasser M., Sheikh M.M. and Manzoor N. 2005. Climate Change and Variability in Mountain Regions of Pakistan Implications For Water And Agriculture. Pakistan Journal of Meteorology2 (4),75-89

IMD, Annual Climate Summary. 2010. India Meteorological Department, Pune $(\mathrm{MH})$. Government of India, Ministry of Earth Sciences, pp. 27.

IPCC., 2007a. Climate change: The physical science basis. In: Contribution of Working Group I to the Fourth Assessment Report of the Intergovernmental Panel on Climate Change. Cambridge University Press, Cambridge, UK and New York, USA, pp. 996.

IPCC., 2007b. Climate Change: Impacts, adaptation and vulnerability. 
Contribution of working group II to the fourth assessment report of the IPCC. Cambridge University Press, Cambridge.

Isaac R.K and Issac M. 2017. Vulnerability of Indian Agriculture to Climate Change: A Study of the Himalayan Region State. International Journal of biological, Biochemical, Agricultural, Food and Biotechological Engineering. Vol 11(3), 207-208.

Jethi R., Joshi K. and Chandra N. 2016. Toward Climate Change and Community-Based AdaptationMitigation Strategies in Hill Agriculture. In: Conservation agriculture, Singapore: Springer., pp. 185-202.

Legave, J. M., Blanke, M., Christen, D., Giovannini, D., Mathieu, V. and Oger R. 2013. A comprehensive overview of the spatial and temporal variability of apple bud dormancy release and blooming phenology in Western Europe. International Journal of Biometeorology, 57(2), 317-331.

Meena V.S., Meena S.K., Verma J.P., Meena R.S. and Ghosh B.N. 2015. The needs of nutrient use efficiency for sustainable agriculture. Journal of CleanerProduction. 102:562-563

Moretti C.L. 2010. Climate changes and potential impacts on postharvest quality of fruit and vegetable crops: A review. Food Research International. 43:1824-1832.

Nautiyal P. and Dimri D. C. 2009. Pollination Management in Apple for Sustainable Production. ProgHort 41 (2):139-148.

Nautiyal P., Papnai G. and Manisha. 2017. Impact of adoption of mulching technology in higher apple production in Uttarakhand, Progressive Horticulture, 49(2): 204-207.

Nautiyal, P., Sachan V. K., Papnai G., Tiwari R.K. and Manisha.2017. Improving
Growth, Yield and Profitability in Apple through Mulching in Rainfed Condition in Hilly region of Uttarakhand. Journal of Krishi Vigyan, 6(1):101-104.

NHB, 2018. http://nhb.gov.in/statistics/State_Level/ 2017-18-(Final).pdf

Parmesan C. 2007. Influences of species, latitudes and methodologies on estimates of phenological response to global warming. Global Change Biology. 13(9):1860-1872.

Patz J.A., Campbell-Lendrum D., Holloway T. and Foley J.A. 2005. Impact of regional climate change on human health. Nature 438: 310-317.

Petri J.L. and Leite G.B. 2004. Consequences of insufficient winter chilling on apple tree bud-break. Acta Horticulture 662:53-60.

Rai R., Joshi S., Roy S., Singh O., Samir M. and Chandra A. 2015. Implications of Changing Climate on Productivity of Temperate Fruit Crops with Special Reference to Apple. Journal of Horticulture, 2:2

Rao, G.G.S.N., Rao, A.V.M.S. and Rao, V.U.M. 2009. Trends in Rainfall and Temperature in Rainfed India in Previous Century. Global Climate Change and Indian Agriculture Case Studies from ICAR Network Project. ICAR Publication, New Delhi, India, pp. 71-73

Richardson E. A., Seeley S. D. and Walker D. R. 1974. A model for estimating the completion of rest for Redhaven and Elberta peach trees. Horticultural Science 9: 331-332.

Sharma A., Chanotra1 S., Gupta R. and Kumar R. 2020. Influence of Climate Change on Cocoon Crop Loss under Subtropical Conditions. International Journal of Current Microbiology and Applied Sciences 9(5): 167-171. 
Sharma N. C., Sharma S. D., Verma S. and Sharma C. L. 2013. Impact of changing climate on apple production in Kotkhai area of Shimla district, Himachal Pradesh. International Journal of Farm Sciences 3(1): 81-90.

Singh N., Sharma D. P. and Chand H. 2016. Impact of Climate Change on apple production in India: A Review. Current World Environment 11(1):251259.

Stockle C.O, Nelson R.L., Higgins S., Brunner J. and Grove G. 2010. Assessment of climate change impact on Eastern Washington agriculture. Climate Change. 102(1): 77-102.

Vedwan N. and Rhoades R.E. 2001. Climate change in the Western Himalayas of India: a study of local perception and response. Climate Resilient19:109-117.

Verma A.K, Gora J.S, Singh J. and Chaudhary D.R. 2019. Climate Change and Production of Horticultural Crops.
Agriculture Impact of Climate Change. CRC Press. pp.45-61

Vitasse, Y., Schneider, L., Rixen, C., Christen, D., and Rebetez, M. 2018. Increase in the risk of exposure of forest and fruit trees to spring frosts at higher elevations in Switzerland over the last four decades. Agricultural and Forest Meteorology, 248, 60-69.

Wani F.A. and Songara M. 2017. Production and Marketing of Apple in Himachal Pradesh: An Empirical Study. International Journal of Research Culture Society. 1(10): 34-40

Zavalloni C., Andresen J.A., Black J.R., Winkler J.A. and Guentchev G. 2008. A preliminary analysis of the impacts of past and projected future climate on sour cherry production in the Great Lakes Region of the USA. Acta Horticulture. 803: 123-130.

\section{How to cite this article:}

Pankaj Nautiyal, Ritika Bhaskar, Gaurav Papnai, Neeraj Joshi and Varun Supyal. 2020. Impact of Climate Change on Apple Phenology and Adaptability of Anna Variety (Low Chilling Cultivar) in Lower Hills of Uttarakhand. Int.J.Curr.Microbiol.App.Sci. 9(09): 453-460. doi: https://doi.org/10.20546/ijcmas.2020.909.057 